\title{
The influence of the world economic crisis in Serbia, the measures of the government, the role of the IMF and the trade union response
}

\begin{abstract}
The world economic crisis is not the cause of the economic crisis in Serbia, but the consequences of the global economic crisis will, to a great extent, certainly also appear in Serbia, primarily in the form of a reduction in the inflow of credit funds and foreign direct investment and in the form of a reduction in demand for domestic goods abroad and a difficulty in marketing our products outside the borders of Serbia. The measures that the Serbian government introduced in the period between January and August 2009, as a means of relieving the consequences of the global economic crisis, are enforced and short-term in character and are more a way of 'fire fighting' instead of being a pattern for a long-term way out of the crisis and for the development of the Serbian economy. The government has also expressed hesitancy in its decision-making and in the introduction of these specific measures.
\end{abstract}

Keywords: economic crisis, government measures, social dialogue, trade union positions.

\section{Introduction}

The economic crisis in Serbia is 'the Serbian crisis', 'the crisis of domestic production'. Namely, there was an economic crisis in Serbia before the global financial and economic crisis. Serbia has not been spared the impact of the world economic crisis but its influence has grown more visible each day.

The accumulated economic problems of previous years have increased the negative effects of the global economic crisis. The failed privatisation process has had an adverse impact on the social rights of employees which in recent months, among other things, has been reflected in a growing number of strikes.

In this paper will be explained: the economic situation in Serbia before the creation of the global economic crisis; the impact of the global economic crisis; the measures of the Serbian government that have been taken to minimise the negative effects of this influence; the arrangement with the International Monetary Fund (IMF); and the trade union response. 


\section{Crisis before crisis}

The world economic crisis has found the Serbian economy in a state which (in the last two decades) may be characterised by the issues explained in the following sub-sections:

Decrease in industrial production

Over the past twenty years, there has been a marked decline in industrial production in Serbia. For example, if the level of industrial production was on the basis of August $2009=100$, the same index in 1989 amounted to 300 .

Table 1 - Index of Serbian industrial production, $1989-2009(2003=100)$

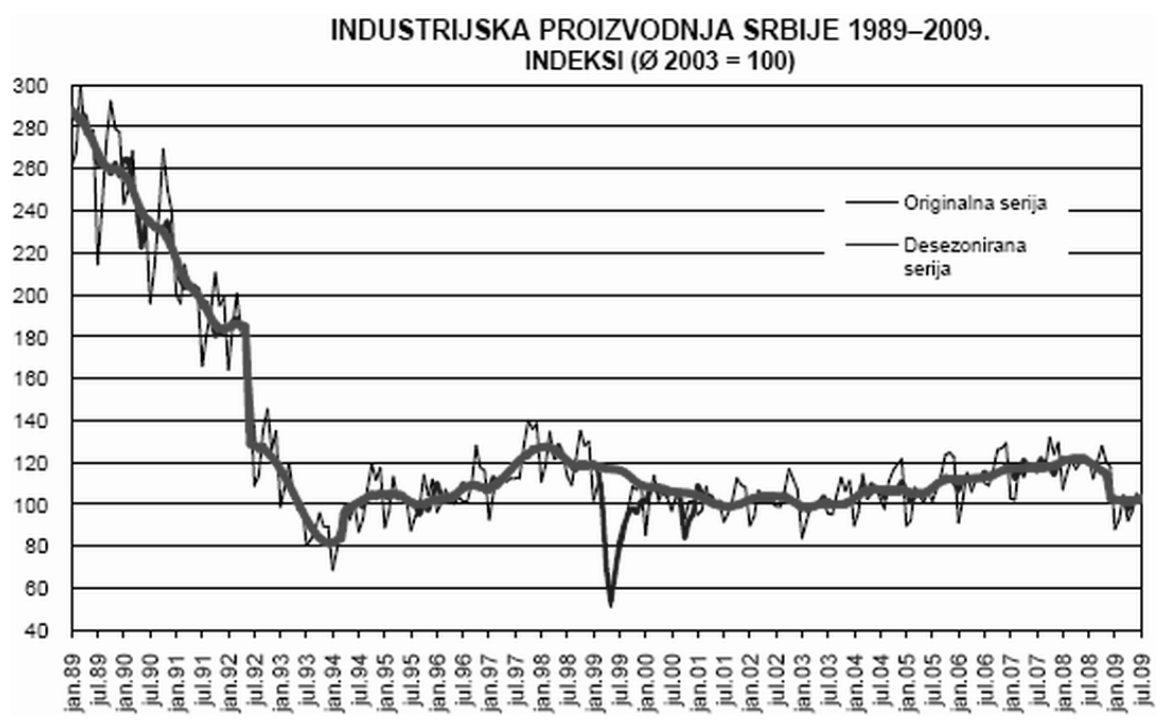

Source: Institute of Economic Sciences (2009) MAT-Macroeconomic Analysis and Trends Year VI, No. 177/178, Belgrade, July/August, p. 1

Decline in gross domestic product

Despite the relatively high rates of GDP growth in the period between 2001 and 2008 (from $4.5 \%$ to $7.1 \%$ ), the level of GDP achieved in 2007 did not even reach $60 \%$ of its 1989 level.

\section{High unemployment rate}

The unemployment rate, representing the numbers of unemployed people in the total active population (employed and unemployed) in Serbia, according to the methodology of the Labour Force Survey, was 14.0\% in October 2008 (12.1\% of the male and $16.5 \%$ of the female population). The unemployment rate had risen, again according 
to the Labour Force Survey, to $15.6 \%$ in April 2009. However, according to the National Employment Service, the unemployment rate calculated on the basis of the number of people who are registered unemployed, amounted to $26.54 \%$ in August 2009. In some municipalities in Serbia, the unemployment rate was even higher than $50 \%$, indicating that, in those municipalities, the number of unemployed people exceeds the number of employees.

High rate of inflation

In the 2001-2008 period, the inflation rate as measured by the growth in retail prices was high and ranged from $6.6 \%$, which was recorded in 2006, to the $40.7 \%$ recorded in 2001. From 1 January 2009, the inflation rate has been calculated on the basis of the consumer price index.

\section{Deficit in current account payments}

This comes primarily from the deficit in foreign trade.

High share of public expenditure in GDP

In the past twenty years, public spending has been very high as a percentage of GDP, with the average ranging above $45 \%$.

The level of public expenditure is now about $44 \%$ of GDP; this was one of the basic issues at the recently held meeting of the Serbian government with the mission of the IMF.

\section{High share of the shadow economy}

According to some estimates, the number of people engaged in the informal economy in Serbia ranges between 600000 and 700 000, while the level of the shadow economy as a percentage of GDP is over $36 \%$.

\section{Large insolvent businesses}

In June 2009, there was a total of 108332 registered small, medium and large sized enterprises. Of this total number, 70182 companies, or $64.8 \%$, are insolvent or bankrupt. Over the last year around 37000 businesses have been declared bankrupt, with total commitments of about 143 bn dinars. The number of entrepreneurs whose accounts are blocked amounts to 35064 with a total debt of around 13 billion dinars.

\section{A large amount of external debt}

The total external debt of the Republic of Serbia amounted on 31 August 2009 to $€ 21725 \mathrm{~m}$ (of which the public external debt amounted to $€ 6870 \mathrm{~m}$ and the private $€ 14855 \mathrm{~m}$ ). According to the indicators of external debt, Serbia is classified as a medium-indebted country. Public debt amounted to 30.6\% of GDP on 30 September 2009.

The amount of foreign debt was $\$ 1444$ per capita in 2000, but $\$ 4230$ at the end of August 2009. It is estimated that external debt in the Republic of Serbia will, by the 
end of 2009 , have reached about $\$ 4800$, or 3.3 times more than the position at the end of 2000 .

\section{Difficulty in maintaining the dinar exchange rate}

The average euro exchange rate is higher than it has been in recent years: for example, one euro was worth 60.4 dinars in 2002 and 84.1 dinars in 2006; but there are now more than 94 dinars per euro.

A number of unfinished examples of, and weaknesses in, privatisation

The main objectives of privatisation in Serbia were, amongst others:

1. create an effective market economy, with an appropriate ownership structure

2. initiate production

3. develop the economy

4. maintain the existing level of employment and secure its increase in the medium term.

However, instead of all this there has been de-industrialisation and even greater unemployment, followed by increased misery and poverty. A large number of enterprises have been privatised, not to start production or see its increase, but facilities and construction sites have been sold at much higher prices than those at which they were purchased.

High levels of corruption

\section{A high percentage of poor people}

In the Republic of Serbia, the number of the poor in 2009 was higher by 107000 on 2008 levels and today reaches over 700000 people. According to EU standards, some $13.2 \%$ of the population in Serbia were in poverty in 2008, while on the Serbian methodology, the figure is $7.9 \%$.

The existence of financial indiscipline, reflected in the mass avoidance of taxes and fees

\section{Problems in the functioning of the pensions system and disability insurance}

The deterioration of the position of the pensions system in Serbia has had a particularly negative impact:

a) unfavourable long-term demographic trends and an increasingly aging population. The participation of younger generations in the total population is low and is on a declining trend, while the participation of the elderly is high and has a tendency towards growth. With $16.8 \%$ of the population being older than 65 years, Serbia ranks among the five oldest countries in the world ${ }^{1}$

1 Participation of those over 65 in the total population in central Serbia amounted to: 1950 , $5.5 \% ; 1970,8.8 \% ; 1995,13.8 \%$; and $2000,16.1 \%$. It is estimated that, in 2021 , the figure will rise to $21.5 \%$; and, by 2051 , even to $31.3 \%$. The median age, which was 38.9 years in 2000 , 
b) the unfavourable ratio between the number of employees and the number of those who are retired. For each retired employee there is, on average, 1.6 employees (and 1.4 insured ones). Improving this ratio means increasing employment and reducing the shadow economy

c) the reducing number of employees and the increasing number of years spent in retirement. Serbia in the period since 1991 has been in a process of de-industrialisation. The number of employees was lower by 463000 in April 2009 compared to December 2001

d) the avoidance of the payment of contributions for pensions insurance. According to the Ministry of Finance - Tax Administration, the total debt on the basis of contributions on behalf of employees' pensions and disability insurance amounted to $58.95 \mathrm{bn}$ dinars as at 31 March 2009, of which 38.3bn dinars related to the main debt and 20.6bn dinars related to interest ${ }^{2}$

e) contributions on the lowest base, not the real income level

f) a high share of the informal, shadow economy in the overall economy. It is estimated that more than 700000 people work in the grey economy in Serbia

g) relaxed conditions for retirement over a longer period of time:

- the share of the population with a disability pension is high $(23 \%)$

- the share of pensioners older than 65 , including those with old age pensions is $62.3 \%$ of insured employees

- less than $20 \%$ of pensioners have a 'full' (i.e. fully insured) work experience record

h) the overflow of and surplus in current investment income compared to expenditure in the 1970s and 1980s saw development in other areas, i.e. the construction of various facilities instead of the building-up of surpluses in the pension fund (pension fund assets were used to build health facilities, rehabilitation centres, water facilities, enterprises, mines and other objects)

i) net expenditure on pensions in 2008 amounted to $11.9 \%$ of GDP (333.1bn dinars), while the total expenditure of the Fund for Pensions and Disability Insurance amounted to $14.3 \%$ of GDP (in addition to expenditures on pensions, this includes expenditure on benefits for care and assistance for other people, disability and funeral expenses, the administrative costs of the operation of the Fund and expenditure on the health care contributions of pensioners). These expenses are, according to 2006 data, among the highest in comparison with transition countries that have

will, according to estimates, amount to 44.9 years by 2021 ; and by 2051 to 52.1 years (Penev, 2002).

2 On 2 October 2009, the government of the Republic of Serbia adopted a conclusion on behalf of senior employees for whom employers have not paid pensions and disability insurance contributions. The conclusion will be linked paths for approximately 80000 employees for the period between 1 January 2004 and 30 June 2009. The last linking pension was claimed in 2005 and covered the period between 1991 and 2003. Then, according to the Pensions Fund, claims were filed on behalf of 360000 people, in respect of whom a positive resolution was given for 264000 . Employees have been paid up to the value of 556000 years of service, which cost the country 18.6 bn dinars. 
joined the EU; but they are slightly lower than the EU average and they are among the lowest in comparison with EU-15 countries

j) the high deficit in the Pensions Fund. Nearly $40 \%$ of the funds required for the payment of pensions is provided through transfers from the national budget. The deficit on regular expenditure amounted to $3.8 \%$ of GDP in 2007 and to $4.4 \%$ in 2008

k) the low level of the pension relative to earnings. In 2008, the pension for insured employees amounted to $59.2 \%$ of average earnings. Over $60 \%$ of pensioners receive a pension which is lower than the average level

1) pensioners are among the most vulnerable groups of the population in the Republic, although the poverty rate of pensioners is lower than the average for the total population (according to the Living Standards Measurement Survey, the relative figures were $5.3 \%$ and $6.6 \%$ in 2007 )

m) problems with the pensions insurance of farmers. In 2008, the average old age pension of farmers (7 446 dinars) was lower by $67.1 \%$ than the average old age pension for categories of employees (22 634 dinars)

n) the hypothetical net replacement rate $^{3}$ for men with forty years of service and an average level of earnings amounted in 2008 to approximately $73 \%$. This was slightly lower than in the EU-15 but, in the long run, this will have been reduced to unacceptably low levels; for example, in 2020 it will amount to just $43 \%$.

\section{Influence of the global economic crisis on the Serbian economy}

The impact of the global economic crisis on the economy of Serbia is primarily manifested in the following forms:

- a reduction in the inflow of credit funds and foreign direct investment

- a reducing demand for domestic goods abroad and a more difficult placement of our products outside of Serbia

- a fall in domestic demand due to the local population refraining from making major purchases

- a decrease in the prices of many export products (for example, metal products)

- a general increase in uncertainty and instability in business

- a reduction in the credit activity of banks (banks with loan approval companies are in difficulty in assessing the effects that the crisis will have on their business - the growth of such uncertainty will, inevitably, be reflected in the margins that banks charge and this will in turn have an impact on growth rates)

- a refraining from borrowing in the economic sector.

Industrial production in Serbia decreased by $10.0 \%$ in August 2009 compared to August 2008 , and by $14.8 \%$ compared to the average for 2008 as a whole. Industrial

3 The hypothetical net replacement rate means the ratio between the pension and the last realised earnings of a hypothetical employee with a full work record (40 years) with an incomes around the level of average earnings. Hypothetical net replacement rates, on the basis of the EC-ISG methodology, equals the net pension at retirement which would be received by an average worker (with a personal coefficient of 1 ) with forty years of service (personal point of 40x general point) divided by average net earnings in the last year. 
production in the January - August 2009 period decreased by $16.2 \%$ on the same period in 2008.

In December 2008, the total number of people employed was 1990342 while it was 1835250 in August 2009; this means that the number of employees has reduced by 155092 in the last nine months.

These influences of the global financial crisis on Serbia's economy will inevitably reflect on the overall standard of living of our citizens and on their ability to exercise their social rights.

\section{The basic content of the Serbian government's measures for mitigating the negative effects of the global economic crisis}

In the period between January and August 2009, the government of the Republic of Serbia brought four 'packages of measures' to mitigate the consequences of the economic crisis. We briefly here consider the content of these 'packages'.

\section{First 'package of measures'}

The government of the Republic of Serbia, at a meeting held on 29 January 2009, adopted a programme of measures to mitigate the negative effects of the global economic crisis in the Republic of Serbia (hereinafter: the Programme). ${ }^{4}$

The Programme was built around two groups of measures:

1. measures aimed at overcoming the negative effects of the global economic crisis

2. measures aimed at encouraging foreign investment and exports.

The basic objectives of the measures within the Programme were: increasing the liquidity of the economic sector; reducing the cost of finance (grants towards interest payments); maintaining the number of employees at the existing level and stimulating new employment; stimulating domestic demand in certain durable consumer goods sectors which employ a significant number of workers; and the preservation of the dynamics of export growth in terms of reduced overseas demand.

\section{Second 'package of measures'}

On 7 April, the Serbian government announced the 'final' raft of measures to mitigate the consequences of the economic crisis with its Plan for the Economic Stability of Serbia. ${ }^{5}$ This consisted of two parts: the first consists of savings measures and cuts in the state administration to the value of nearly one billion euros; while the other consists of incentives for the economy.

The main content of the proposed measures is as follows:

1. reduce expenditure by 90 billion dinars

2. reduce the number of employees in public administration

4 Conclusion of the Government of the Republic of Serbia No. 05: 4-472/2009, of 29 January 2009.

5 The Serbian government: Government Plan for the Economic Stability of Serbia (http:// www.media.srbija.sr.gov.yu/medsrp/dokumenti/plan_ekonomske_stabilizacije_srbije.pps.). 
3. make additional savings in public administration

4. increase budget revenues -16 billion dinars

5. implement a package of incentives:

a) subsidised loans -162 billion dinars

b) active employment measures.

\section{Third 'package of measures'}

Nevertheless, the government adopted additional stimulus measures aimed at facilitating greater support to the economy when it met on 7 May 2009. These new measures of support for stimulating the economy provide, inter alia, an additional 40 billion in liquidity loans so that the overall package of corporate loans has increased to 180 billion dinars (nearly $€ 2 b n$ ), of which:

1. liquidity loans -4 billion dinars from the state; 80 billion dinars invested by the bank (in dinars or in foreign currency)

2. loans for investment -5 billion dinars provided by the state and 12 billion dinars placed by the bank, giving a total of 17 billion dinars for the economy overall

3. loans from the Development Fund - 18 billion dinars

4. corporate loans from foreign sources -45 billion dinars

5. consumer loans for the purchase of domestic products -1 billion dinars provided by the state; 20 billion dinars invested by the bank

6. additional measures to improve the liquidity of the economy - the regular servicing of public expenditure and its reconciliation to the needs of a balanced budget in the short-term.

In terms of liquidity loans with a foreign currency clause, the interest rate is $3 \%$ per annum (a reduction on the existing 5.5\%); while liquidity loans in local currency see an interest rate amounting to $10.5 \%$ per year (NB the reference interest rate here is reduced by $3.5 \%$ per annum).

The envisaged measures applied from 18 May 2009.

\section{Fourth 'package of measures'}

Finally, the government adopted a social security plan at its meeting on 27 August 2009. This aims to protect the legal rights of employees, preserve jobs and facilitate dialogue between employees and employers.

The government package of measures here is formulated in eight points, namely:

1. payment of contributions for the pensions and health insurance of employees

2. providing one-off financial assistance to socially vulnerable employees

3. re-programming outstanding obligations in respect of electricity (for the most socially vulnerable workers)

4. preventing abuse in the privatisation process

5. swapping state and employee company capital

6. signing the agreement on social partnership

7. providing public meetings

8. forming an operational working group to implement the measures. 


\section{Negotiations with IMF}

On 4 November 2009, the Serbian government completed its negotiations for 2009 with the International Monetary Fund (the second revision of the arrangement) and reached agreement on the terms of the further use of stand-by credit arrangements with the IMF.

Specifically, the IMF Board of Directors had, on 15 May 2009, approved a standby credit arrangement with Serbia which is intended to last until April 2011. This is about seven times higher than the loan to Serbia which the IMF approved in January 2009 , taking it from $€ 402.5 \mathrm{~m}$ to $€ 2.94 \mathrm{bn}$.

The exact dynamics of the withdrawal of funds was to be agreed over the succeeding days and months. Serbia has withdrawn a loan of $€ 788 \mathrm{~m}$ from the IMF, while the remaining money will be forthcoming in equal tranches during the arrangement since it is estimated that the financial tensions will, by its conclusion, have abated. ${ }^{6}$

The main issues during the talks with the Serbian government were: the budgets for 2009 and 2010; fiscal and monetary policies after 2010; reform of the pensions system; and the public sector. During the negotiations, the IMF agreed to the following targets:

\section{Budget}

- 2009 deficit: $4.5 \%$ of GDP

- 2010 deficit: $4 \%$ of GDP

- cover of deficit credit borrowing (World Bank, EU, Russian loan)

Inflation

- for 2009: $8 \%,+/-2 \%$

- for 2010: $6 \%,+/-2 \%$

Foreign exchange

- stabilisation of the dinar

- a flexible exchange rate regime continuing in 2010

Economic growth

- for 2009, a decrease of $3 \%$

- for 2010 , growth of $1.5 \%$

Taxes

- no increase in VAT

- expansion of the tax base

- a fairer taxation of property

6 Website of the Government of the Republic of Serbia: News - Belgrade, 4 November 2009: Successfully completed negotiations between the Government of Serbia and the IMF. 


\section{Pensions}

- a beginning of gradual reforms commencing in 2010

- continuation of the freeze in pensions during 2010

- alignment in 2011, on basis of a growth formula which has yet to be determined

- stricter criteria for early retirement

- reduction of AVC in respect of work experience

- no decrease in pensions for those who fulfil the requirement for retirement in terms of years of service, and no minimum age for retirement

- a reform proposal to be prepared by the end of February

Public sector

- continuation of the freeze in earnings in 2010

- rationalisation of the administration

This arrangement brings forth the following:

\begin{tabular}{|l|l|l|}
\hline Year & Source of funds & Amount of funds \\
\hline 2009 & World Bank loan & $\$ 200 \mathrm{~m}$ \\
\hline 2010 & Part of the World Bank loan & Part of $\$ 300 \mathrm{~m}$ \\
\hline 2009 & Donation from EU & $€ 50 \mathrm{~m}$ \\
\hline 2010 & Donation from EU & $€ 100 \mathrm{~m}$ \\
\hline 2010 & Help from EU & $€ 200 \mathrm{~m}$ \\
\hline
\end{tabular}

\section{Trade union attitudes}

In connection with the proposed government measures

The Shorter Book of measures taken by the government, and the top-line measures from the first three 'packages', shows us that it has no clear vision or programme for an exit from the crisis. Its moves are too incoherent, tired, imbalanced and ponderous.

The attitude of the Confederation of Autonomous Trade Unions of Serbia (CATUS) regarding the 'fourth' package of measures is that the proposals are acceptable to the trade union, since they are largely in accordance with the requirements of the CATUS protest held on 29 April 2009 and the requests made to the Council to resolve the problem of employees in the privatisation process and in the conditions of economic crisis.

The general strike and protest actions were organised as a means of expressing dissatisfaction with the more difficult material and social aspects of the status of employees, unemployed people, pensioners, young people and most citizens of Serbia and, in particular, because:

- the salaries and pensions on which people can not live, their 'freezing' and the announcement of an additional 'solidarity' tax 
- the disastrous effects of privatisation on the economy which, instead of the promise of growth, has inspired a dramatic drop in output and the continuous closure of factories and enterprises

- the failure to comply with collective agreements and the implementation of the restrictive provisions of the law (Article 28 of the Law on the Budget of the Republic of Serbia for 2009)

- the dismissal of workers and the lengthy and inefficient resolution of labour disputes

- the lack of a genuine social dialogue in which each of the social partners may demonstrate responsibility.

CATUS supported the package of social measures but expressed dissatisfaction in that had not been consulted in connection with the reduction of the number of employees in local government.

\section{Strikes}

In Serbia, at the end of August 2009, strikes were taking place in 48 companies employing around 20000 employees.

Common characteristics of the majority of strikes are:

1. they have no relationship with the world economic crisis

2. they are a consequence not of private property as such but of the chosen model of privatisation, which most workers on strike criticise as 'predatory'.

The main demands of the strikers were:

1. payment of salary arrears (some have received no payment for years)

2. payment of contributions for pensions and health insurance

3. cancellation of privatisation

4. obtaining or sub-dividing shares

5. control by the state over whether the new owner respects the contract of sale

6. support for the country to find the finance to continue production

7. compliance with court decisions and other requirements on actions brought by workers.

\section{Attitudes regarding trade union negotiations with the IMF}

\section{The problem of the budget deficit}

The view of CATUS is that the problem of the budget deficit needs - among other things - to be resolved, involving measures both on the expenditure and on the revenue side of the budget. These include:

a) reduction of public spending in the first place via measures that will provide significant savings and better control of the expenditure budget, which is now inadequate. In other areas, the following measures are necessary, among others:

- harmonisation of government ministries with real requirements (in the ministries, among other employees, there are nearly 300 state secretaries and assistant ministers)

- reduction in the number of government agencies, administration bodies, directorates and others 
- harmonisation of employees in the public sector with real requirements

- better control of public procurement carried out from budgetary funds

- application of the Law on the State Audit Institution

- production of the final budget accounts, which has not been done for years

- implementation of austerity measures.

b) better control of billing and the collection of public revenues, i.e. taxes and contributions for mandatory social insurance (pensions and disability insurance, insurance against health and unemployment). The very poor rate of collection of taxes and contributions means that over 100000 employees have problems in terms of their seniority for pensions insurance, as well as for the realisation of their rights in the field of health insurance

c) reducing the share of the shadow economy in a real, sustainable way.

In the Republic of Serbia, the informal economy employs more than 700000 citizens and its share of gross domestic product is over $30 \%$, which is significantly higher than in European Union countries (14\%). Reducing the grey economy by just $5 \%$ would halve the budget deficit.

The most common forms of the grey economy in the Republic of Serbia are:

- operation contracts concluded on the work of registered employers

- working on contracts of employment in violation of the rights of employees (nonpayment of overtime; non-payment of compulsory social insurance contributions; the calculation of contributions for compulsory social insurance on the basis of the minimum wage; etc.)

- work with unregistered employers.

\section{Reducing the number of employees in the national and local authorities}

When it comes to the issue of reducing the number of employees in national and local bodies, CATUS thinks that the announced rationalisation is necessary; but that, however, it needs to be made in accordance with the applicable law with criteria for the reduction in the number of employees' which are both transparent and objective.

The Confederation of Autonomous Trade Unions of Serbia is not a subject of consultation when it comes to the Law on determining the maximum number of employees in local administration.

\section{Reform of pensions and disability insurance}

As regards the reform of pensions and disability insurance, CATUS believes that the main problem lies in the non-payment of contributions for pensions and disability insurance by a large number of employers. The result of this is a very high deficit in the Pensions Fund (nearly $40 \%$ of the funds required for the payment of pensions is provided from the national budget).

So far, the changes made to the system of pensions and disability insurance, based on the Labour Laws of 2001, 2003 and 2005, and especially the changes to the law in 2005, have significantly and adversely affected the living standards of pensioners.

In accordance with the 2005 amendments to the Law, the pension in the Republic of Serbia is, from 1 January 2009, now fully indexed only with the movement in the 
cost of living (the gradual abandonment of the so-called Swiss formula), while the level below which a pension can not fall in relation to the amount of average earnings ( $60 \%$ of average earnings) has been abolished. Currently, the average pension is $59.2 \%$ of average earnings.

In our opinion, the anticipated increase in the retirement age of women no longer has any justification bearing in mind that, among other things, Serbia has nearly 800000 unemployed people; life expectancy is shorter than in European Union countries; there is a large number of jobs based on hard manual labour; working conditions are significantly poorer than in many European countries; etc. According to the current law, women will work for two additional years to 60 and the level that exists in most European countries.

The main efforts of CATUS concerning the question of the reform of pensions and disability insurance are reflected in the following areas: the adjustment (indexation) of pensions and the return of the Swiss formula; the means of the harmonisation of the general points (adjustments based on movements in wages) to determine the lower limit of the average level of pensions in relation to average earnings (between $60 \%$ and $70 \%)$; determination of the lower level of the lowest pensions (25-30\% of average earnings); a solution to the problem of the property of the Pensions Fund (the Institute for Rehabilitation and others); the efficient payment of contributions for mandatory pensions insurance; the establishment of a central Register for policyholders and pensioners; and solutions to the issues of farmers and others.

\section{Increase in VAT}

CATUS is against the increase in value added tax, but believes that the economy must remove all unnecessary benefits.

\section{The basic question}

The main question for CATUS is the taking of the measures necessary to lead to the revival of production, to job creation and to a raising of the overall standard of living of the population. In one word, the basic question is of the provision of the conditions for economic growth and development.

In the process of privatisation since 2001, over 400000 people have been left without a job and there has been a full de-industrialisation (destroyed have been the electrical industry; the mechanical industry; engines and tractors; the chemical industry; the textile industry; etc.). 


\section{References}

Vera Glassner and Bela Galgoczi (2009): Plant-level responses to the economic crisis in Europe ETUI-REHS research department (WP 2009.01): Brussels.

Institute of Economic Sciences (2009): MAT - Macroeconomic Analysis and Trends Year VI, No. 177/178, Belgrade, July/August.

Rajko Kosanović (2008) Mobing: psihički teror na radu Radnička štampa: Belgrade.

Rajko Kosanović and Sanja Paunović (2008) Pristojan rad (Decent work) Radnička štampa: Belgrade.

Rajko Kosanović (2008) Sindikalne teme Radnička štampa: Belgrade.

Rajko Kosanović (2007) Konvencije i preporuke Međunarodne organizacije rada Radnička štampa: Belgrade, December.

Rajko Kosanović and Sanja Paunović (2008) Sindikat u zaštiti prava zaposlenih Zbornik radova: Zaštita prava iz radnog odnosa, Glosarijum: Belgrade.

National Bank of Serbia (2008) Izveštaj o stanju u finansijskom sistemu Belgrade, Septembar.

Sanja Paunović and Rajko Kosanović (2009) Siva ekonomija (Hidden economy) Radnička štampa: Belgrade.

Law on the budget of the Republic of Serbia for 2009 (Official Gazette of the Republic of Serbia бp. 120/08).

Law amending the Law on the budget of the Republic of Serbia for 2009 (Official Gazette of the Republic of Serbia бp. 31/09).

Law on the temporary reduction of salaries and wages, net of fees and other increments in public administration and the public sector (Official Gazette of the Republic of Serbia бp. 31/09).

Conclusion of the Government of the Republic of Serbia No. 05: 4-472/2009 of 29 January 2009.

Serbian government: Government plan for the economic stability of Serbia (http:// www.media.srbija.sr.gov.yu/medsrp/dokumenti/plan_ekonomske_stabilizacije_srbije.pps)

Serbian government News Belgrade, 4 November 2009: 'Successfully completed negotiations of the Government of Serbia and the IMF'. 